Session 2460

\title{
Core Educational Competencies and A Systems Response
}

\author{
Saeid Y. Eidgahy, Ph.D., San Diego Mesa College
}

\begin{abstract}
Many different ideas and concepts in educational reform have been studied and discussed throughout the past two decades. Engineering education, in particular, is undergoing major transformation under the new EC2000. Quality concepts are increasingly entering the culture of colleges and accreditation agencies now consider outcomes assessment to be of the highest importance. These are all important developments for engineering educators, but what is missing is a link among the many valuable, but disconnected, ideas and activities. This paper presents a unified approach in that core or basic competencies are carefully discussed and analyzed. A second component of the paper will then present the necessary components of a systems response to the achievement of competencies.
\end{abstract}

The author will present a discussion in the following segments:

1) Base competencies;

2) General competencies for engineering education;

3) Paradigm shift on program evolution; and

4) Systems approach to educational transformation.

This paper is not intended to provide definitive answers to today's reform demands, but rather construct the necessary parameters for a systems method of responding to educational change. As such, this paper will provide useful tools for practitioners.

\section{Base Competencies}

Educational institutions and business and industry enterprises need to cooperate on the preparation of students for entering complex occupations of today's information economy. Since educators and business representatives often speak varying languages in terms of needs and how to prepare for them, there is a strong desire to find a common set of concepts that are understandable and operational by both sides. As our economy and newly created jobs require more competency-based education than ever before, this has become increasingly a critical link. Four basic concepts may serve as a foundation for such common approach to education: self-management, communication, management of people and tasks and taking advantage of creativity, change and innovation ${ }^{1}$.

Self-management refers to a constant effort in developing personal practices that enhance a person's skills in dealing with the uncertainty of change. Most of what our students 
learn in college programs is obsolete by graduation. It then becomes highly important that students develop life-long skills in living and taking advantage of change that is necessary and inevitable in today's careers. Communications is constantly cited as a basic need in all work environments. What is particularly critical in engineering education is the ability to communicate effectively with people who have preparations other than engineering. In other words, in order for a new innovative technical project to be funded, a marketing manager or someone with an accounting or management background must be convinced of its benefits. An engineer must be able to constantly communicate in verbal and written forms with non-engineers. This will facilitate the gathering, integrating and conveying of information in many formats.

Engineers often work as part of a team composed of many members with varied backgrounds. As a result, developing skills in managing other people and accomplishing required tasks is a universal requirement for any engineer. This may involve planning, organizing, coordinating and even controlling business resources (capital, equipment, etc) as well as people. And finally, the only certain aspect of change in our work and lives today is the fact that it will occur. Engineers have long been pioneers of creativity, innovation and change that have been employed for the betterment of human lives. With the constant change in today's economy, engineers need skills and knowledge in mobilizing innovation and change toward positive ends more than ever before.

\section{General Competencies for Engineering Education}

In 1997, the Society of Manufacturing Engineers convened a national forum to study and discuss the educational requirements in engineering (and particularly manufacturing) for the $21^{\text {st }}$ century. As a result of this effort, major competency gaps were identified in the educational preparation of engineers needing to be addressed. These included: communication, teamwork, personal attributes, business skills, change management and continuous learning ${ }^{2}$. These competency gaps form a basic requirement for engineering education. Paramount to successful careers is solid skills in oral presentation skills, writing skills and graphic communication skills. Such abilities should also include good listening abilities and meeting organization and facilitation. All engineers are required to participate in interdisciplinary work teams. Effective participation and interaction includes the ability to recognize others' contributions while learning from their knowledge, resolving potential conflicts, understanding diversity and being accountable to other team members.

On a more personal level, integrity and professionalism are critical aspects for today's engineers, while having a global awareness and building consensus among coworkers are increasingly significant. While engineers have solid technical credentials, our programs have not optimized their general business skills such as basic economics, entrepreneurship, customer focus and methods of risk analysis. As members of larger working teams, engineers should be prepared as business professionals as well to function effectively. As mentioned previously, change is an inevitable fact of life. The most effective method of dealing with constant change is being an agent of change. One of the basic skills needs in engineering education is to learn long and short-term effects 
management. And finally, learning is not a milestone, retaining of knowledge is not a discrete event and thus, today's engineers must be able to learn throughout their careers and lives on a continuous basis.

These competency requirements were also confirmed through an activity sponsored by NSF, ASEE and ABET in $1997^{3}$. Essentially, engineering technician education was required to focus more on issues of critical thinking, problem solving, teambuilding and lifelong learning also. In a more global study, researchers reviewed how curriculum design could be modified in response to current and future trends, while still remaining consistent with basic institutional practices. As a result, four overall learning outcomes were identified: active learning, critical/creative/reflective thinking, clear and original communication skills, and interaction in diverse and complex environments ${ }^{4}$. With the exception of active learning other components have been confirmed through other studies already cited. Active learning is an interactive process resulting in greater expertise and more comprehensive understanding of concepts and issues at hand. As all of these studies confirm, engineering education has prepared great technical professionals, but requires more and significant emphasis on general competencies.

\section{Paradigm Shift on Program Evolution}

Program evolution in higher education has been a painstakingly slow process and gradual at best. New requirements and needs of our competitive economy no longer allows for such processes to take their normal time. A number of base and general competencies for engineering education have been identified through research and multiple validation processes. Now, we must integrate these skills into our curriculum that is arguably the most difficult part of this transformation. In order to be successful in this effort, institutions must be totally committed to required reforms regardless of how difficult some may be to achieve. This requires a total paradigm shift in our curricular response ${ }^{5}$. This shift will require institutions to change the classroom focus to active and perhaps collaborative learning; however, this can't be done without a substantial commitment to faculty professional development in new pedagogy. Higher education has become and will continue to be market-driven and today's learners have many more choices in available learning venues. With the explosion in technology capability, the concepts of learning at anyplace and anytime is no longer a vision, it's here. The quality movement, which took industry by storm some decades ago, is now making impressive inroads into higher education. Since engineering has been a fundamental creator of quality concepts, engineering education programs should now allow TQM concepts to take hold in academic programs. This does mean losing some control over curriculum, but in the longer term ensures much greater success in meeting our constituent needs, both students as well as businesses and industries who will employ them. In an era of electronic revolution, engineering programs must ensure that core general education requirements are met more than ever before. 


\section{Systems Approach to Educational Transformation}

So, how do we make all of this transformation happen? One effective method of doing this is to employ a comprehensive systems approach and the following five steps: systems thinking, systems design, quality approach, management of change and employing appropriate instructional technology ${ }^{6}$. Systems thinking allows educators to avoid being continuously distracted by passing fads. It allows for major overhauling changes to take place, which will have a powerful overall effect on our curriculum efforts. Once an engineering program has embraced this way of thinking, appropriate design would be the next step. Systems design enables engineering educators to make necessary changes and improvement a very deliberate process. Under this design, small or incremental changes which affect only a tiny portion of our programs is not adequate. This approach mandates a recreation of how we design educational programs for future engineers and technical professional. In other words, we must gain the tools to create an entirely new curriculum ensuring core competencies are achieved.

One of the major problems which engineering educators have faced is a disparity between certain aspects of academic programs and industry needs. By employing a quality science mode, faculty can ensure the production of programs that meet industry demands and expectations. Quality science allows us to continuously improve our programs, obtain a good investment return of our faculty and material resources and forces everyone to view quality as an everyday aspect of everyone's job; which is exactly what has been adopted by many businesses and industries. The information revolution, constant advance in technology and global competition make engineering as a discipline a highly dynamic one. This requires change on an almost daily basis and thus, management of that change will be a critical aspect of what we do in engineering education evolution. Change management allows us to drive the change process and take advantage of creative energy in making positive change. And finally, instructional technology is our fifth step in the transformation of engineering education. While we must use all resources to employ effective technology in our programs, we must also remain cognizant that technology in a means not an end by itself. In other words, engineering faculty should use effective instructional design to take advantage of technology. Many employers are offering their own customized education programs, the higher education marketplace is being flooded with private for-profit colleges, many established institutions are now offering a significant degree of distance education and so forth. In other words, engineering programs must learn to operate in a highly competitive education market and instructional technology can play an important and positive role in that.

In summary, a significant body of research has been completed to identify basic as well as general competencies in engineering as presented here. We have also discussed how such needs mandate us to view engineering curricular needs in a completely new way and establish a paradigm shift among our faculty and administrators. And finally, the author 
has attempted to provide clear guidelines as a path in transforming engineering programs. While this paper does not attempt to present conclusive information, the author hopes it does provide a much need path for the discussion of necessary change.

\section{Bibliography}

1. Evers, F.T., Rush, J.C. \& Berdrow, I. The bases of competence: Skills for lifelong learning and employability. San Francisco, CA: Jossey-Bass (1998).

2. Society of Manufacturing Engineers. Manufacturing education plan: Phase I report. Dearborn, MI: Society of Manufacturing Engineers (1997).

3. National Science Foundation. A national agenda for the future of engineering technician education. Arlington, VAQ: National Science Foundation (1997).

4. Wilson, C.D., Miles, C.L., Baker, R.L. \& Schoenberger, R.L. Learning outcomes for the $21^{\text {st }}$ century. League for Innovation in the Community College and The Pew Charitable Trust (2000).

5. Van Dusen, G.C. The virtual campus: Technology and reform in higher education. ASHE-ERIC Higher Education Report Volume 25, Number 5 (1997).

6. Salisbury, D.F. Five technologies for educational change. Englewood Cliffs, NJ: Educational Technology Publications (1996).

\section{SAEID Y. EIDGAHY}

Saeid Y. Eidgahy is currently the dean of the School of Mathematics and Natural Sciences at San Diego Mesa College. He was dean and a professor of Engineering Technologies, Applied and Computer Sciences at Jefferson Community College previously. Saeid has taught at both two year and four year college as well as graduate level engineering technology programs. He has published widely and presented at numerous national conferences on engineering, technology, workforce and minorities in engineering issues.

"Proceedings of the 2001 American Society for Engineering Education Annual Conference \& Exposition Copyright 2001, American Society for Engineering Education” 